\title{
FINANCIAL CONSTRAINTS IN POLAND. THE ROLE OF SIZE AND POLITICAL CONNECTIONS
}

This article investigates the phenomenon of financial constraints in investment activities. Using a data set covering 2001-2011, we established that, despite the institutional changes and the financial system development, Polish firms remain financially constrained by the internally available funds. Additionally, we explored the impact of size and political connections on financial constraints. Unexpectedly we found that the financial constraints are not affected by either the size or the type nor the strength of political connections.

Keywords: financial constraints, political connection, investment

DOI: $10.15611 /$ aoe.2016.1.09

\section{INTRODUCTION}

According to the assumptions of the Modigliani-Miller theorem (Modigliani and Miller, 1958), in a world of perfect capital markets the actual cash position of a company is irrelevant to its investment policy. In such a world, the availability of capital makes the internal and external sources of investment financing perfectly substitutable. However the empirical evidence proves that this assumption does not hold in the real world, where the investment activities of companies are financially constrained by their internal cash positions. The traditional explanation concentrates on the information asymmetry between corporate insiders and the capital markets as the main factor that affects the financial constraints (FC) phenomenon (Myers and Majluf, 1984).

There have been many studies concerning the issue of FC that concentrate on different aspects of this phenomenon. One area of research is the effects of the development of capital markets and liberalization of FC. Ghosh (2006) analyzed the market liberalization process in India and its positive impact, which results in an easing of the FC. A similar issue was studied in China by Chan et al. (2012a). These authors found that large firms encountered no credit constraints, and smaller firms displayed significant constraints; however the sensitivity of large firm investments to cash

\footnotetext{
* Department of Banking and Insurance, Kozminski University, Warsaw

** Department of Finance, Kozminski University, Warsaw
} 
positions grew during the sample period. According to the authors, the observed process could be the result of market liberalization, which eliminates preferential treatment for large, previously state-owned and politically connected companies. Moreover, no decrease in FC can be observed for small firms, which could mean that the financial reforms in China are not sufficient to benefit this type of company. The weaker sensitivity of older and larger companies to FC was also noted by Beck et al. (2006). Furthermore, Lagoarde-Segot (2013), found that financial market development and international integration are not sufficient conditions to ease the FC on local firms.

An interesting area of research is the phenomenon of $\mathrm{FC}$ in transition economies, particularly regarding the capital market development and the liberalization observed in these countries. Konings et al. (2003) used panel data of more than 4,000 manufacturing firms annual observations from 1994 to 1999 to investigate the influence of financial constraints on the investment activities of companies in Poland, the Czech Republic, Bulgaria and Romania. The researchers found that as a result of soft budget constraints in Romania and Bulgaria, companies from those two countries were less sensitive to internal financing than companies from Poland and the Czech Republic. Guariglia et al. (2012) also conducted research on financial constraints in Poland, Romania, Bulgaria and the Czech Republic, that addressed the problem of irreversible investments and their sensitivity to FC. The researchers concluded that financially constrained firms with a high degree of irreversible investments may be reluctant to invest. Therefore the irreversibility of investments may reduce the investment-cash flow sensitivities for firms that are financially constrained.

The FC phenomenon is modified by the presence of political connections. Chan et al. (2012b) investigated to what extent the political connections of Chinese firms affected the level of perceptible constraints in the financing of their investments. The researchers gathered a database of 1,347 entities that were monitored during 2005-2007. The results of the research proved that Chinese companies are financially constrained, however the observed effects solely concerned the companies that were not politically connected. A similar issue was investigated by $\mathrm{Xu}$ et al. (2011) in the context of Chinese family-owned businesses in the 2000-2007period. The starting point for Xu et al. (2011), as with Chan et al. (2012b), was to check whether the monitored firms experienced any financial constraints in the financing of investments. The answer to that question was positive because the business investments of family-owned firms were significantly dependent on the cash flow from operational activities. 
Our study contributes to the literature in several ways. Firstly, and most importantly, the impact of political connections on FC has not yet been studied in Poland or in any other post-transition European economy. The literature addresses the issue of FC's existence in Poland solely by using data from the early period of transformation (Konings et al., 2003) or within the specific context (Guariglia et al. 2012). Thus our research complements and significantly enriches the findings of Konings et al. (2003) and fills a gap in the literature on the subject. Secondly, we are the first to investigate how the potential strength of political connections modifies the relation between political factors and the FC phenomenon. Thirdly, the economic role of political connections in Central European economies in general has been rarely studied (Jackowicz 2013; Jackowicz et al. 2013; Hasan et al. 2014; Jackowicz et al. 2014). Therefore our study adds to the literature that pertains to the importance of political connections in post-transition countries.

\section{HYPOTHESES}

Konings et al. (2003) established that company investments were sensitive to internally generated funds in Poland and the Czech Republic from 1994 to 1999. Since then, Poland and other transitional countries have undergone deep institutional changes. Consequently it is interesting to check whether Polish enterprises remain financially constrained. Thus, we propose the following hypothesis H1.

H1: Investment decisions of Polish firms depend on available internal funds.

The literature demonstrated that politically connected firms in developing economies have easier access to bank loans (for example Khwaja and Mian, 2005; Faccio 2006; Claessens et al., 2008; Liu et al., 2012; Bliss and Gul, 2012; Boubakri et al. 2012). Moreover, Houston et al. (2012) showed that in the U.S. economy, politically connected firms pay lower interest rates on their borrowings. Chan et al. (2012c) and Xu et al. (2011) found, in turn, that investments of politically connected Chinese firms, in contrast to other enterprises, were insensitive to internal funds. Therefore we posit that politically connected firms in Poland should be less constrained in their investment processes by internal resources than their unconnected competitors. Consequently, we test the hypothesis $\mathrm{H} 2$. 
H2: The sensitivity of investment decisions to internally generated funds is lower for a group of politically connected firms than for their unconnected peers.

Political connections are more frequent and valuable in regulated industries or in industries that rely heavily on government contracts (Agarwal and Knoeber, 2001; Bunkanwanicha and Wiwattanakantang, 2009; Kang and Zhang, 2012). Therefore we expect that the impact of political connections on financial constraints is stronger for firms classified as regulated, dependent on procurement contracts or treated as strategically important. Therefore we test the following hypothesis $\mathrm{H} 3$.

H3: The softening of financial constraints is more pronounced for politically connected firms that represent regulated, dependent on government contracts and strategically important industries than for enterprises from other industries.

Ceteris paribus, large firms are usually viewed by capital market participants as more financially viable. Consequently the problem of financial constraints should be more acute for entities with small-sized operations. This reasoning leads us to the fourth hypothesis $\mathrm{H} 4$.

H4: The investment decisions of small firms, regardless of their political connections, are more strongly linked to internally generated funds than those of large enterprises.

Several works (Khwaja and Mian 2005; Claessens et al. 2008; Malesky and Taussig 2009; Lazzarini et al. 2012) show that in the context of bank lending, strong political connections are particularly valuable. Therefore we also posit that the FC phenomenon weakens when a firm's political ties are strong. We express our expectations in hypothesis H5.

H5: The financial constraints of firms diminish when they possess strong political connections, i.e. ties with influential politicians.

Our sample period encompasses the recent financial crisis. Consequently we have a unique opportunity to study whether political connections gained in significance during a difficult economic period. Both the theoretical reasoning and the existing empirical evidence (Hasanet al. 2014) suggest that this may be the case. Thus we propose the following final hypothesis H6.

H6: The reduction in financial constraints for politically connected firms is more pronounced during an economic crisis than in other periods. 


\section{DATA AND METHODOLOGY}

We analyse the financial constraints of Polish listed, non-financial firms over the 2001-2011 period. Two factors influenced the choice of our sample. First, we concentrate solely on non-financial firms because the investments of financial and non-financial organizations are non-comparable. Second, we limit our sample to listed companies for which we were able to gather the necessary financial information, as well as detailed information on management and supervisory board composition. All the firm-specific

Table 1

The political connections in different industries

\begin{tabular}{|c|c|c|c|c|}
\hline \multirow{3}{*}{$\begin{array}{l}\text { Industry (according } \\
\text { to the classification } \\
\text { applied by the } \\
\text { Notoria service) }\end{array}$} & \multicolumn{4}{|c|}{$\begin{array}{l}\text { Politically connected firms through: } \\
\end{array}$} \\
\hline & \multicolumn{2}{|c|}{ supervisory board members } & \multicolumn{2}{|c|}{ management board members } \\
\hline & $\begin{array}{c}\text { \# of } \\
\text { politically } \\
\text { connected } \\
\text { firms } \\
\end{array}$ & $\begin{array}{l}\% \text { of firms } \\
\text { within an } \\
\text { industry }\end{array}$ & $\begin{array}{c}\text { \# of } \\
\text { politically } \\
\text { connected } \\
\text { firms } \\
\end{array}$ & $\begin{array}{l}\% \text { of firms } \\
\text { within an } \\
\text { industry }\end{array}$ \\
\hline construction & 11 & $34.4 \%$ & 3 & $9.4 \%$ \\
\hline developing & 6 & $37.5 \%$ & 3 & $18.8 \%$ \\
\hline power & 3 & $42.9 \%$ & 2 & $28.6 \%$ \\
\hline trade - other & 0 & $0.0 \%$ & 0 & $0.0 \%$ \\
\hline retail trade & 5 & $25.0 \%$ & 1 & $5.0 \%$ \\
\hline wholesale trade & 7 & $25.9 \%$ & 3 & $11.1 \%$ \\
\hline hotels and restaurants & 2 & $33.3 \%$ & 1 & $16.7 \%$ \\
\hline IT & 10 & $31.3 \%$ & 0 & $0.0 \%$ \\
\hline media & 5 & $31.3 \%$ & 0 & $0.0 \%$ \\
\hline industry - other & 0 & $0.0 \%$ & 0 & $0.0 \%$ \\
\hline chemicals & 4 & $80.0 \%$ & 3 & $60.0 \%$ \\
\hline wood and paper & 2 & $33.3 \%$ & 1 & $16.7 \%$ \\
\hline electro-engineering & 7 & $26.9 \%$ & 2 & $7.7 \%$ \\
\hline pharmaceuticals & 1 & $20.0 \%$ & 0 & $0.0 \%$ \\
\hline light industry & 1 & $12.5 \%$ & 0 & $0.0 \%$ \\
\hline building materials & 2 & $12.5 \%$ & 0 & $0.0 \%$ \\
\hline metal & 5 & $27.8 \%$ & 1 & $5.6 \%$ \\
\hline automotive & 2 & $33.3 \%$ & 0 & $0.0 \%$ \\
\hline fuel & 3 & $60.0 \%$ & 2 & $40.0 \%$ \\
\hline food & 6 & $26.1 \%$ & 0 & $0.0 \%$ \\
\hline raw materials & 3 & $60.0 \%$ & 0 & $0.0 \%$ \\
\hline plastic & 2 & $33.3 \%$ & 0 & $0.0 \%$ \\
\hline telecommunication & 3 & $42.9 \%$ & 0 & $0.0 \%$ \\
\hline services - other & 7 & $35.0 \%$ & 1 & $5.0 \%$ \\
\hline Total/Mean & 97 & $30.7 \%$ & 23 & $7.3 \%$ \\
\hline
\end{tabular}

Source: authors' own 
financial information was retrieved from the Notoria database. Using these data source, we created an unbalanced panel of more than 2,000 observations for 316 non-financial entities. The information on political connections was hand-collected while the information on top managers and members of the supervisory boards was provided by the InfoVeriti service. We assume, in accordance with the literature, that firms are politically connected when at least one member of its management team or supervisory board has political experience in government, national parliament, local parliaments or in regulatory bodies. According to this definition, 105 firms were classified as politically connected in one or more years of the period studied. Table 1 provides more information on political connections in our sample. As shown, political connections through supervisory boards are much more frequent than through managerial positions. The share of politically connected entities within industries varies significantly between $0 \%$ and $80 \%$. As Figure 1 demonstrates, political connections in Poland are usually established on the level of central political powers, i.e. the government and the parliament. Further information pertaining to the phenomenon of political connectedness in Poland are presented by Jackowicz (2013).

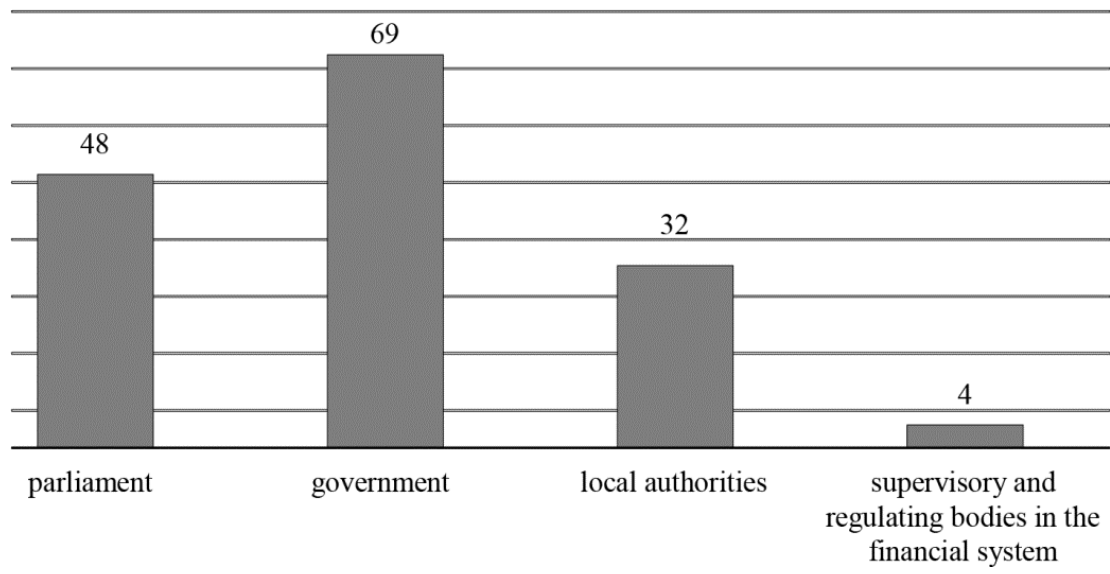

Figure 1.The number of politically connected firms through different political bodies

Source: authors' own

To test our hypotheses we apply a dynamic panel model. There are three main reasons behind our choice. First, the structure of data requires the use of a panel model because we observe the same entities over a long period. Second, investment activities may exhibit persistence because investment 
programmes are frequently realized in several stages. Third, when we use financial ratios from the same period, the question of endogeneity arises. Therefore we decided to adopt the GMM-SYS procedure proposed by Blundell and Bond (1998). The GMM technique has the disadvantage that the statistical inference based on the estimated models is only possible after several econometric conditions are met. We will return to this issue in Section 4 when we present our empirical findings.

The general construction of our models is illustrated by Equation (1).

$$
\operatorname{INVEST}_{i t}=g\left(\begin{array}{l}
\text { INVEST }_{i t-1} ; \text { CONTR }_{i t-1} ; \text { INTF }_{i t-1}, \text { PCON }_{i t}, \text { SMALL }_{i t}, \\
\text { PCON_Type }_{i t}, \text { CRISIS }, T x I_{j t}
\end{array}\right)
$$

In Equation (1)'s encoding, $i$ is for firms, $j$ is for industries, and $t$ is for time periods. INVEST denotes the dependent variable, INTF is a set of independent variables that measures the amount of available internal funds, and CONTR is a set of explanatory variables designed to control for other factors than those related to internal funds as determinants of investment activity. PCON and SMALL are binary variables that identify the politically connected and small firms, respectively. PCON_Type constitutes a set of binary variables that describe the level on which political connections are established. The binary variable CRISIS identifies the sub-period 2008-2011, whereas $T x I$ is a set of dummies that control for specific conditions in year $t$ in industry $j$.

The dependent variable (INVEST) is calculated as a quotient of fixed assets purchased and the value of total fixed assets lagged by one period. The set of control variables (CONTR) includes the measure of financial leverage (LEV), the market value to book value ratio (MV/BV) and the return on sales ratio calculated at the level of gross profit (loss) on sales (ROS_S). To test our main hypothesis (H1), we alternatively use two measures of internally available funds: CASH and WCASH. The CASH variable is defined in accordance with the literature standards as cash scaled by property plant and equipment. The WCASH shares the denominator with the CASH variable, but has the sum of cash and cash equivalents in the numerator. We test the hypothesis $\mathrm{H} 2$ using the interactions terms PCONxCASH and PCONxWCASH, where the binary variable PCON is equal to one for politically connected firms in a given year. To test the hypothesis H3, we introduce three binary variables: GOV_CONTR, REGULATED and STRATEGIC and interact these with the PCON and CASH variables. The GOV_CONTR variable identifies firms from the IT, 
construction, energy production and distribution industry sectors. The REGULATED variable is equal to one for firms from the pharmaceutical, energy production and distribution, natural resources, telecommunication, and alcohol production and distribution industry sectors. The STRATEGIC variable encodes entities from energy production and distribution, oil and petroleum production and distribution, and the chemical and natural resources industry sectors. The hypothesis $\mathrm{H} 4$ is tested using the variable SMALL, which indicates firms with assets below the median. To test H5, we introduce three binary variables: PCON_PARL; PCON_GOV and PCON_LOCAL, which indicate whether a firm employs persons with parliamentary, governmental or local political experience, respectively. We conjecture that members of parliament or ministers are more influential than politicians from local authorities. Therefore the variables PCON_PARL and PCON_GOV identify prima facie strong political connections. We test the final hypothesis H6 interacting with the binary variable CRISIS, which controls for the changed economic environment during and after the recent crisis, with the variable PCON.

\section{EMPIRICAL RESULTS}

All the models presented in Tables 2 to 4 have good econometric properties that enable us to draw statistical and economic inference. First, the explanatory variables are jointly statistically significant, usually at the $1 \%$ level. Second, the Sargan test for over-identifying restrictions, which is based on a two-step GMM estimator, confirms the validity and correct choice of the instruments. Third, the AR(1) and AR(2) tests suggest that the disturbances are not serially correlated. This is because there is evidence of a significant negative first-order serial correlation in the differenced residuals and no evidence of a second-order correlation in the differenced residuals. Fourth, several regressors are individually statistically significant. Fifth, the significant explanatory variables influence the dependent variable in a stable manner because the relevant coefficients preserve their signs and orders of magnitude despite the alterations in model constructions.

The control variables influence the investment activity in the expected directions when they are statistically significant. In specifications (1), (2) and (3), firms with better prospects, captured by the MV/BV variable, report higher investment expenses. As expected, the investment process is easier for more profitable entities (ROS_M). Interestingly, in the case of the lagged dependent variable (INVEST), the null hypothesis that the estimated 
coefficients are equal to zero cannot be rejected at the conventional levels. This finding means that Polish firms do not exhibit strong investment persistence.

The empirical evidence gathered in Table 1 clearly supports H1. All the parameters obtained for the CASH variable and two of the three coefficients estimated for WCASH variables are positive and statistically significant at least at the 5\% level. Thus we conclude that the phenomenon identified by Konings et al. (2003) has not disappeared. Listed firms in Poland remain financially constrained by internally available funds in their investment decisions. Moreover, the impact of cash holdings on investment is highly significant in economic terms. For example, when we use the estimation results for specification (2) in Table 1, we observe that a shift in the distribution of the CASH variable from the $10^{\text {th }}$ to the $90^{\text {th }}$ percentile intensifies the investment activity by $19 \%$ of the INVEST variable mean value in our sample.

In contrast to $\mathrm{H} 1$, the estimation results contradict $\mathrm{H} 2$. In our sample, political connections do not eradicate the financial constraints because both interaction terms CASHxPCON and WCASHxPCON are insignificant. The aforementioned outcome should be qualified as surprising when we consider that numerous researchers found that politically connected firms enjoyed preferential access to bank loans.

We proceed to testing $\mathrm{H} 3$ and $\mathrm{H} 4$ in Table 2. As shown, the control variables do not change their significance or the directions of their impact on investment activities. Furthermore, in specification numbers (7) to (12), the main variable that tests for the existence of financial constraints (CASH) preserves the positive and statistically significant coefficients.

Contrary to our expectations expressed in H3, firms from regulated, strategically important and reliant on government contracts industries are not less financially constrained than the remainder of our sample. All triple interaction terms (PCONxREGULATED, PCONxSTRATEGICxCASH, PCONxGOV_CONTR_CASH) in specifications (7), (8) and (9) are insignificant. Therefore regarding financial constraints, there is no basis in Poland to claim that political connections are more valuable for certain groups of industries.

The GMM estimates in Table 2 also falsify H4. Relatively small listed firms, independent of being politically connected or unconnected, do not suffer from worse financial constraints in their investment processes than their large competitors. The interactions terms SMALLxCASH and PCONx SMALLXCASH that would corroborate $\mathrm{H} 4$ are statistically insignificant. 
Table 2

Financial Constraints in Poland - Results of H1 and H2 Tests

\begin{tabular}{l|r|r|r|r|r|r|r|r|r|r|r|r}
\hline & $(1)$ & & $(2)$ & $(3)$ & & $(4)$ & $(5)$ & $(6)$ & \\
\hline DINVEST & 0.008 & & 0.008 & & 0.005 & & 0.012 & & 0.012 & & 0.002 & \\
\hline & $(0.037)$ & & $(0.038)$ & $(0.038)$ & & $(0.039)$ & & $(0.039)$ & & $(0.038)$ & \\
\hline DCASH & 0.080 & $* * *$ & 0.080 & $* * *$ & 0.076 & & & & & & & \\
\hline & $(0.016)$ & & $(0.016)$ & & $(0.017)$ & & & & & & & \\
\hline DWCASH & & & & & & & 0.037 & $* *$ & 0.037 & $* *$ & 0.027 & \\
\hline & & & & & & & $(0.017)$ & & $(0.017)$ & & $(0.016)$ & \\
\hline DLEV & 0.414 & & 0.421 & & 0.338 & & 0.336 & & 0.346 & & 0.223 & \\
\hline & $(0.337)$ & & $(0.339)$ & & $(0.286)$ & & $(0.399)$ & & $(0.397)$ & & $(0.314)$ & \\
\hline DMV/BV & 0.032 & $*$ & 0.032 & $*$ & 0.034 & $* *$ & 0.012 & & 0.011 & & 0.015 & \\
\hline & $(0.017)$ & & $(0.017)$ & & $(0.017)$ & & $(0.014)$ & & $(0.014)$ & & $(0.012)$ & \\
\hline DROS_M & 0.482 & $* * *$ & 0.486 & $* * *$ & 0.472 & $* * *$ & 0.551 & & 0.553 & $* *$ & 0.484 & $* *$ \\
\hline DPCON & $(0.173)$ & & $(0.173)$ & & $(0.167)$ & & $(0.221)$ & & $(0.221)$ & & $(0.212)$ & \\
\hline & & & -0.050 & & -0.066 & & & & -0.020 & & -0.097 & $*$ \\
\hline DPCONxCASH & & & & & 0.019 & & & & & & & \\
\hline & & & & & $(0.067)$ & & & & & & & \\
\hline DPCONxWCASH & & & & & & & & & & & 0.061 & \\
\hline & & & & & & & & & & & $(0.042)$ & \\
\hline Constant & -0.201 & & -0.204 & & -0.149 & & -0.149 & & -0.155 & & -0.078 & \\
\hline & $(0.199)$ & & $(0.200)$ & & $(0.166)$ & & $(0.241)$ & & $(0.239)$ & & $(0.190)$ & \\
\hline no. of observations & 1016 & & 1016 & & 1016 & & 1022 & & 1022 & & 1022 & \\
\hline Wald (joint) & 46.6 & $* * *$ & 47.19 & $* * *$ & 43.99 & $* * *$ & 16.62 & $* * *$ & 16.5 & $* *$ & 31.92 & $* * *$ \\
\hline AR(1) test & -3.656 & $* * *$ & -3.646 & $* * *$ & -3.684 & $* * *$ & -3.374 & $* * *$ & -3.37 & $* * *$ & -3.491 & $* * *$ \\
\hline & -1.239 & & -1.239 & & -1.267 & & -1.441 & & -1.441 & & -1.35 & \\
\hline
\end{tabular}

Notes: All models include the time and industry dummies (TxI). This table presents the one-step GMM-SYS estimates. Control variables are lagged by one period. The robust standard errors are provided in parentheses. ${ }^{* * *},{ }^{* *}$, and ${ }^{*}$ indicate significance at the $1 \%, 5 \%$, and $10 \%$ levels, respectively.

Source: authors' own

As the specifications (13) to (15) contained in Table 4 demonstrate, the type of political experience possessed by members of the supervisory or managerial boards is irrelevant. All the interaction terms, including the variable CASH and the variables PCON_GOV, PCON_PARL and PCON_LOCAL, are statistically insignificant. Consequently we obtain no evidence that prima facie stronger political connections are more efficient in easing the FC problem in Poland, as implied by H5. The last empirical result corroborates our previous findings, however they are in contrast with certain outcomes reported in the literature. We will discuss the reasons behind Poland's specificity regarding the role of political connections in the next section. 
Table 3

Financial Constraints in Poland - Results of H3 and H4 Tests

\begin{tabular}{|c|c|c|c|c|c|c|c|c|c|c|c|c|}
\hline & (7) & & (8) & & (9) & & (10) & & (11) & & (12) & \\
\hline \multirow[t]{2}{*}{ DINVEST } & 0.009 & & 0.009 & & 0.008 & & 0.028 & & 0.028 & & 0.029 & \\
\hline & $(0.038)$ & & $(0.038)$ & & $(0.038)$ & & $(0.040)$ & & $(0.040)$ & & $(0.040)$ & \\
\hline \multirow[t]{2}{*}{ DCASH } & 0.081 & & 0.080 & 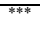 & 0.080 & & 0.108 & & 0.108 & & 0.095 & \\
\hline & $(0.016)$ & & $(0.016)$ & & $(0.016)$ & & $(0.047)$ & & $(0.047)$ & & $(0.047)$ & \\
\hline \multirow[t]{2}{*}{ DLEV_N } & 0.434 & & 0.422 & & 0.423 & & 0.166 & & 0.173 & & 0.155 & \\
\hline & $(0.338)$ & & $(0.341)$ & & $(0.339)$ & & $(0.305)$ & & $(0.304)$ & & $(0.275)$ & \\
\hline \multirow[t]{2}{*}{ DMV/BV } & 0.034 & ** & 0.032 & & 0.033 & & 0.038 & ** & 0.038 & w* & 0.039 & \\
\hline & $(0.017)$ & & $(0.017)$ & & $(0.017)$ & & $(0.017)$ & & $(0.017)$ & & $(0.017)$ & \\
\hline \multirow[t]{2}{*}{ DROS_M(-1) } & 0.485 & F** & 0.486 & **** & 0.488 & **** & 0.460 & $* * *$ & 0.463 & **** & 0.462 & \\
\hline & $(0.173)$ & & $(0.173)$ & & $(0.172)$ & & $(0.170)$ & & $(0.171)$ & & $(0.168)$ & \\
\hline \multirow[t]{2}{*}{ DPCON } & -0.021 & & -0.054 & & -0.057 & & & & -0.064 & & -0.054 & \\
\hline & $(0.034)$ & & $(0.043)$ & & $(0.044)$ & & & & $(0.039)$ & & $(0.043)$ & \\
\hline \multirow[t]{2}{*}{$\begin{array}{l}\text { DPCONxGOV } \\
\text { CONTRxCASH }\end{array}$} & -0.053 & & & & & & & & & & & \\
\hline & $(0.039)$ & & & & & & & & & & & \\
\hline \multirow[t]{2}{*}{$\begin{array}{l}\text { DPCONxREGULATEDx } \\
\text { CASH }\end{array}$} & & & 0.056 & & & & & & & & & \\
\hline & & & $(0.043)$ & & & & & & & & & \\
\hline \multirow[t]{2}{*}{$\begin{array}{l}\text { DPCONXSTRATEGICX } \\
\text { CASH }\end{array}$} & & & & & 0.773 & & & & & & & \\
\hline & & & & & $(0.625)$ & & & & & & & \\
\hline \multirow[t]{2}{*}{ DPCONxCASH } & & & & & & & & & & & -0.008 & \\
\hline & & & & & & & & & & & $(0.077)$ & \\
\hline \multirow[t]{2}{*}{ DSMALLxCASH } & & & & & & & -0.037 & & -0.037 & & -0.025 & \\
\hline & & & & & & & $(0.048)$ & & $(0.049)$ & & $(0.050)$ & \\
\hline \multirow[t]{2}{*}{ DPCONxSMALLxCASH } & & & & & & & & & 0.047 & & 0.052 & \\
\hline & & & & & & & & & $(0.046)$ & & $(0.084)$ & \\
\hline \multirow[t]{2}{*}{ Constant } & -0.216 & & -0.209 & & -0.206 & & -0.059 & & -0.063 & & -0.048 & \\
\hline & $(0.199)$ & & $(0.201)$ & & $(0.200)$ & & $(0.177)$ & & $(0.177)$ & & $(0.158)$ & \\
\hline No. of observations & 1016 & & 1016 & & 1016 & & 1016 & & 1016 & & 1016 & \\
\hline Wald (joint) & 49.83 & $3 * *$ & 49.91 & ***; & 49.44 & 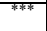 & 44.9 & & 55.97 & & 58.2 & \\
\hline Sargan test (two-step) & 65.24 & & 59.05 & & 54.15 & & 54.3 & & 52.37 & & 50.75 & \\
\hline $\mathrm{AR}(1)$ test & -3.69 & *** & -3.644 & ***** & -3.645 & **** & -3.7 & *** & -3.674 & ***** & -3.666 & \\
\hline $\mathrm{AR}(2)$ test & -1.188 & & -1.245 & & -1.22 & & -1.047 & & -1.03 & & -1.066 & \\
\hline
\end{tabular}

Notes: All models include the time and industry dummies (TxI). This table presents the onestep GMM-SYS estimates. Control variables are lagged by one period. The robust standard errors are provided in parentheses. ${ }^{* *},{ }^{* *}$, and ${ }^{*}$ indicate significance at the $1 \%, 5 \%$, and $10 \%$ levels, respectively.

Source: authors' own

The modified macroeconomic and financial situation in Poland after 2008 does not alter the significance of political connections. The triple interaction term in specification (16) in Table 4, including the binary variable CRISIS, is again insignificant. Therefore our research does not support H6, which claims that political connections are particularly important during difficult times. In interpreting this outcome, we must remember that the Polish economy was affected by the recent crisis to a lesser degree than other European economies. Consequently the need to use political connections, at least theoretically, was not as urgent. 
Table 4

Financial Constraints in Poland - Results of H5 and H6 Tests

\begin{tabular}{|c|c|c|c|c|c|c|c|c|}
\hline & 13 & & 14 & & 15 & & 16 & \\
\hline \multirow[t]{2}{*}{ DINVEST } & 0,004 & & 0,005 & & 0,005 & & 0,005 & \\
\hline & 0,039 & & 0,038 & & 0,038 & & 0,038 & \\
\hline \multirow[t]{2}{*}{ DCASH } & 0,075 & **** & 0,077 & ${ }^{* * * *}$ & 0,076 & **** & 0,076 & \\
\hline & 0,017 & & 0,017 & & 0,017 & & 0,017 & \\
\hline \multirow[t]{2}{*}{ DLEV_N } & 0,311 & & 0,322 & & 0,305 & & 0,346 & \\
\hline & 0,281 & & 0,280 & & 0,281 & & 0,283 & \\
\hline \multirow[t]{2}{*}{$\mathrm{DMV} / \mathrm{BV}$} & 0,034 & *** & 0,034 & ** & 0,034 & ${ }^{* *}$ & 0,034 & \\
\hline & 0,016 & & 0,017 & & 0,016 & & 0,017 & \\
\hline \multirow[t]{2}{*}{ DROS_M(-1) } & 0,474 & ${ }^{* * * *}$ & 0,464 & ${ }^{* * *}$ & 0,465 & **** & 0,473 & \\
\hline & 0,166 & & 0,167 & & 0,166 & & 0,168 & \\
\hline \multirow[t]{2}{*}{ DPCON } & $-0,068$ & & $-0,067$ & & $-0,063$ & & $-0,066$ & \\
\hline & 0,041 & & 0,051 & & 0,049 & & 0,050 & \\
\hline \multirow[t]{2}{*}{ DPCONxCASH } & 0,017 & & 0,013 & & 0,000 & & 0,029 & \\
\hline & 0,076 & & 0,070 & & 0,075 & & 0,034 & \\
\hline \multirow[t]{2}{*}{ DPCON_PARL_X_CASH } & 0,016 & & & & & & & \\
\hline & 0,083 & & & & & & & \\
\hline \multirow[t]{2}{*}{ DPCON_LOCAL_X_CASH } & & & 0,060 & & & & & \\
\hline & & & 0,064 & & & & & \\
\hline \multirow[t]{2}{*}{ DPCON_GOV_X_CASH } & & & & & 0,020 & & & \\
\hline & & & & & 0,088 & & & \\
\hline \multirow[t]{2}{*}{ DPCONxCASHxCRISIS } & & & & & & & $-0,011$ & \\
\hline & & & & & & & 0,064 & \\
\hline \multirow[t]{2}{*}{ Constant } & $-0,131$ & & $-0,140$ & & $-0,129$ & & $-0,150$ & \\
\hline & 0,163 & & 0,162 & & 0,164 & & 0,165 & \\
\hline No. of observations & 1016 & & 1016 & & 1016 & & 1016 & \\
\hline Wald (joint) & 52,27 & & 96,17 & & 45,58 & ${ }^{* * * *}$ & 58,49 & \\
\hline Sargan test (two-step) & 57,94 & & 57,55 & & 53,95 & & 60,03 & \\
\hline $\mathrm{AR}(1)$ test & $-3,696$ & *** & $-3,675$ & *** & $-3,687$ & *** & $-3,683$ & \\
\hline $\mathrm{AR}(2)$ test & $-1,264$ & & $-1,303$ & & $-1,275$ & & $-1,281$ & \\
\hline
\end{tabular}

Notes: All models include the time and industry dummies (TxI). This table presents the one-step GMM-SYS estimates. Control variables are lagged by one period. The robust standard errors are provided in parentheses. ${ }^{* * *},{ }^{* *}$, and ${ }^{*}$ indicate significance at the $1 \%, 5 \%$, and $10 \%$ levels, respectively.

Source: authors' own

\section{CONCLUDING REMARKS}

Despite the institutional changes and the financial system's development, listed firms in Poland remain constrained by internally generated funds in their investment decisions. Thus, our empirical results corroborate the 
findings of Konings et al. (2003). The identified relation is surprisingly strong. In the extreme case when a hypothetical firm migrates from the $5^{\text {th }}$ to the $95^{\text {th }}$ percentile in the distribution of the variable that describes the internal funds, the investment activity increases by more than $25 \%$ of the mean value in the sample. We assume that the FC problem is more acute for non-listed firms, which have more limited access to both bank loans and capital markets. Thus the financial constraints phenomenon in Poland constitutes an important problem from a policy-making perspective.

Contrary to expectations, the financial constraints phenomenon was neither affected by the scale of operations nor by the political connections and their type. The result concerning the insignificance of political connections when shaping the financial constraints of Polish firms is prima facie positive from a social and economic perspective. However, we are not inclined to ascribe the insignificance of political connections fully to the exceptional efficacy and transparency of democratic institutions as well as to the low corruption levels in Poland. Recent research (Amore and Bennedsen, 2013) identified a large positive effect of political connections on the profitability of firms related to local politicians in Denmark, one of the world's least corrupt countries. Therefore we hypothesize that in Poland the reduction in the significance of political connections was, at least partially, caused by the instability of the political environment during the sample period. From 2001 to 2011, Poland witnessed several major cabinet reshuffles and had six different prime ministers. Other discrepancies between our empirical findings and the expectations formulated on the basis of the literature may be explained by the fact that the Polish economy weathered the stormy period of the recent financial crisis very well. Therefore the specificity of Poland in regard to financial constraints and political connections is, in our opinion, linked mainly to the instability of the political scene and the favourable macroeconomic conditions during the sample period.

\section{REFERENCES}

Agarwal, A., Knoeber, C. R., Do Some Outsider Directors Play a Political Role?, “Journal of Law and Economics", 44 (1), pp. 179-198, 2001.

Amore, M. D., Bennedsen, M., The Value of Local Political Connections in a Low-corruption Environment, "Journal of Financial Economics", 110, pp. 387-402, 2013.

Beck, T., Demirguc-Kunt, A., Laeven, L., Maksimovic, V., The Determinants of Financing Obstacles, "Journal of International Money and Finance", 25, pp. 932-952, 2001. 
Bliss, M. A., Gul, F. A., Political Connection and Leverage: Some Malaysian Evidence, "Journal of Banking and Finance", 36, pp. 2344-2350, 2012.

Blundell, R. W., Bond, S. R., Initial Conditions and Moment Restrictions in Dynamic Panel Data Models, "Journal of Econometrics", 87, pp. 115-143, 1998.

Boubakri, N., Cosset, J. C., Saffar, W., The Impact of Political Connections on Firms' Operating Profit and Financing Decisions, "Journal of Financial Research", 35, pp. 397-423, 2012.

Bunkanwanicha, P., Wiwattanakantang, H., Big Business Owners in Politics, "Review of Financial Studies", 22 (6), pp. 2133-2168, 2009.

Chan, K. S., Dang, V. Q. T, Yan, I. K. M. (a), Financial Reform and Financing Constraints: Some Evidence from Listed Chinese firms, "China Economic Review", 23, pp. 482-497, 2012.

Chan, K. S., Dang, V. Q. T, Yan, I. K. M. (b), Chinese Firms' Political Connection, Ownership, and Financing Constraints, "Economics Letters", 115, pp. 164-167, 2012.

Chan, K. S., Dang, V. Q. T., Yan, I. K. M. (c), Effects of Financial Liberalization and Political Connection on Listed Chinese Firms' Financing Constraints, "The World Economy", 35, pp. 483-499, 2012.

Claessens, S., Feijen, E., Laeven, L., Political Connections and Preferential Access to Finance: The Role of Campaign Contributions, "Journal of Financial Economics", 88, pp. 554-580, 2008.

Faccio, M., Politically Connected Firms, “American Economic Review” 96, pp. 369-386, 2006.

Guariglia, A., Tsoukalas, J., Tsoukas, S., Investment, Irreversibility, and Financing Constraints: Evidence from a Panel of Transition Economies, "Economics Letters", 117, pp. 582-584, 2012.

Ghosh, S., Did Financial Liberalization Ease Financing Constraints? Evidence from Indian Firm-level Data, "Emerging Markets Review”, 7, pp. 176-190, 2006.

Hasan, I., Jackowicz, K., Kowalewski, O., Kozłowski, Ł., Politically Connected Firms in Poland and Their Access to Bank Financing, "Bank of Finland", BOFIT Discussion Paper, 2, 2014.

Houston, J. F., Jiang, L., Lin, C., Ma, Y., Political Connections and the Cost of Bank Loans, Available at SSRN, http://dx.doi.org/10.2139/ssrn.1911760, 2012.

Jackowicz, K., Czynniki polityczne w bankowości. Ujęcie empiryczne [Political Factors in Banking. Empirical Approach], Poltext, 2013.

Jackowicz, K., Kowalewski, O., Kozłowski, Ł., The Influence of Political Factors on Commercial Banks in Central European Countries, "Journal of Financial Stability", 9, pp. 759-777, 2013.

Jackowicz, K., Kozłowski, Ł., Mielcarz, P., Political Connections and Operational Performance of Non-financial Firms. New Evidence from Poland, "Emerging Markets Review", 20, pp. 109-135, 2014.

Kang, J-K., Zhang, L., From Backroom to Boardroom: Role of Government Directors in U.S. Public Firms and Their Impact on Performance, Available at SSRN, http://ssrn.com/abstract=2115367, 2012. 
Khwaja, A. I., Mian, A., Do Lenders Favor Politically Connected Firms? Rent Provision in an Emerging Market, "Quarterly Journal of Economics", 120 (4) , pp. 1371-1411, 2005.

Konings, J., Rizove, M., Vandenbussche, H., Investment and Financial Constraints in Transition Economies: Micro Evidence from Poland, the Czech Republic, Bulgaria, and Romania, "Economic Letters",78, pp. 253-258, 2003.

Lagoarde-Segot, T., Does Stock Market Development Always Improve Firm-level Financing? Evidence from Tunisia, "Research in International Business and Finance", 27, pp. 183-208, 2013.

Lazzarini, S. G., Muscacchio, A., Bandeira-de-Mello, R., Marcon, R., What Do Development Banks Do? Evidence from Brazil, 2002-2009. Available at SSRN: http://ssrn.com/abstract=1969843 or http://dx.doi.org/10.2139/ssrn.1969843, 2012.

Liu, J., Uchida, K., Gao, R., Political Connections and the Long-term Stock Performance of Chinese IPOs, "Journal of International Financial Markets", "Institutions and Money", 22, pp. 814-833, 2012.

Malesky, E. J., Taussig, M. D., Where Is Credit Due? Legal Institutions, Connections, and the Efficiency of Bank Lending in Vietnam, "Journal of Law, Economics, and Organization", 25, pp. 535-578, 2009.

Modigliani, F., Miller, M., The Cost of Capital, Corporation Finance, and the Theory of Investment, "American Economic Review", 48, pp. 261-297, 1958.

Myers, S., C., Majluf, S. Corporate Financing and Investment Decisions when Firms Have Information that Investors do not Have, "Journal of Financial Economics", 13 (2), pp. 187-221, 1984.

$\mathrm{Xu}, \mathrm{N} ., \mathrm{Xu}, \mathrm{X} .$, Yuan, Q., Political Connections, Financing Friction, and Corporate Investment: Evidence from Chinese Listed Family Firms, "European Financial Management”, http://doi:10.1111/j.1468036X.2011.00591.x, pp. 1-23, 2011.

Received: October 2013, revised: October 2015 